The successor to the journal Music Review, Nineteenth-Century Music Review aims to locate music within the widest possible framework of intellectual activity pertaining to the long nineteenth century (c.1789-1914). It particularly welcomes interdisciplinary scholarship that explores music within the context of other artistic and scientific discourses. Articles with fine visual or iconographic content are encouraged, as are those rich in musically illustrative material. Articles accepted for publication will reflect a diversity of critical viewpoints.

\title{
Contents of Volume 3, Issue 1
}

Introduction

James Deaville

Articles

Derek B. Scott

Bennett Zon

Ralph P. Locke

Michael V. Pisani

James Deaville

Review Article James R. Currie
Music and Cultures of Racial Representation in the Nineteenth Century

In Search of Genetically Modified Music: Race and Musical Style in the Nineteenth Century

Disorienting Race: Humanizing the Musical Savage and the Rise of British Ethnomusicology

Aida and Nine Readings of Empire

John Philip Sousa's 'Red Indians': A Case Study of Race in Music

African-American Entertainers in Jahrhundertwende Vienna: Austrian Identity, Viennese Modernism and Black Success

Adorno - and Now the Act

Book Reviews

CD Reviews

Score Reviews

Published in association with the Centre for Nineteenth-Century Music, Durham University, UK

Cover illustration: 'Revanche der Strohwitwen: "Wartet, Strohwitwer von 'Venedig in Wien', wir revanchiren uns!"', Humoristische Blätter (18 Apr. 1897), reproduced in Rubey and Schoenwald, Venedig in Wien, p. 71.

\section{ASHGATE}

Ashgate Publishing Limited Gower House, Croft Road

Aldershot, Hampshire

GU11 3HR, England

www.ashgate.com

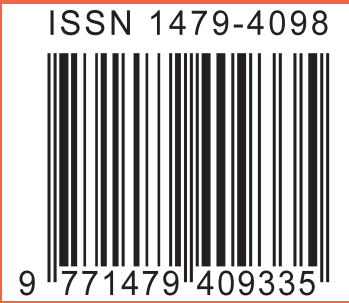

